\title{
Communication on Corporate Social Responsibility and Sustainable Development in France
}

\author{
Ben Mahjoub Lassaad ${ }^{1}$, Halioui Khamoussi ${ }^{2}$ \\ ${ }^{1}$ Department of Accounting and Finance, Faculty of Economic Sciences and Management, Sfax, Tunisia. \\ ${ }^{2}$ College of Economics, Management and Information Systems, Nizwa, Oman
}

cross'ref http://dx.doi.org/10.5755/j01.erem.61.3.1393

(received in February, 2012, accepted in September, 2012)

France is located at the crossroads of major European cultural currents, between Northern Europe and the Mediterranean, her attention to the preservation of corporate social responsibility and sustainable development has evolved in recent years by taking several attempts and measures. Many studies were interested to evaluate the scope of social and environmental disclosure by using different measures; these criteria do not cover all features which can reflect all social and environmental concerns.

We attempt to determine the level of corporate social responsibility disclosure in France by a new measure; it takes the form of an index; for this, we use a content analysis of annual reports in order to evaluate the items which describe the impact of firm activity on the environment and the community.

Compared to other studies, our findings show an acceptable level of social and environmental disclosure made by French companies.

Keywords: Corporate social responsibility; environmental and social disclosure; sustainable development; socially responsible investment; content analysis, France.

\section{Introduction}

\section{Concept of CSR}

Corporate Social Responsibility (CSR) is a cornerstone of contemporary business and society and can result in organizational legitimization, consumer loyalty, and increased organizational financial performance (Dam and Scholtens 2012).

The European Union defines Corporate Social Responsibility as "... the concept that an enterprise is accountable for its impact on all relevant stakeholders. It is the continuing commitment by business to behave fairly and responsibly and contribute to economic development while improving the quality of life of the work force and their families as well as of the local community and society at large..."

\footnotetext{
${ }^{1}$ See the EU Green Paper: Promoting a European Framework for Corporate Social Responsibility
}

The emergence and increasing interest in social and environmental accounting and disclosure reflects the ever-increasing demand for transparency driven by a number of factors, including:

- Societal interest as the mainstream in social and environmental issues;

- Development of the CSR field generally and of CSR standards in particular;

- Increasing demand for new and better information to meet the information needs of different stakeholders. Advances in communication technology;

- Investor's interest in CSR performance as a business issue;

\section{$(18 / 07 / 2001)$}

http://europa.eu.int/comm/employment_social/socdial/csr/greenpaper_en.pdf 
- Declines in the levels of trust afforded to some institutions.

\section{French efforts in the societal ${ }^{2}$ disclosure enhancement}

Since 1977, French companies employing more than 300 people have had to file a "bilan social" (social balance sheet) with their local works councils, firm level components of national trade unions. These annual reports contained data on 134 indicators regarding work and employment situations as well as evaluations of changes that had been made over the last three years. While these documents were not required to be disclosed publicly outside the works councils, social balance sheets were the first step towards mandated CSR disclosure.

In 2001, the French Parliament passed the Nouvelles Regulations Economiques (NRE) or New Economic Regulations Act. Embedded in the NRE is Article 116, mandating that the companies listed publicly on Paris Stock Exchange's Primary Market include social and environmental information in their annual reports. By having such information published in annual reports, Article 116 makes CSR data publicly available to investors and the public.

Article 116 is elaborated in Decree $N^{\circ}$. 2002221, passed in 2002, which explains in detail the specific social and economic indicators that companies are required to report on, in three areas: human resources, community involvement, and the environment. By law, companies are required to produce missing information if asked by shareholders, and shareholders have the ability to sue if they have been harmed by a company's failure to disclose certain information. However, without sanctions or specifications on form, length, or depth, the reporting performance of French companies has varied greatly.

In addition, the French government requires employees' savings funds and public pension funds to define and disclose the social, ethical, and environmental criteria they use when investing. The 2001 Law on the Generalization of Employee Saving Plans mandates that employee saving funds "specify the social, environmental or ethical considerations the fund management company must take into account when buying or selling stocks and securities" and indicates in the annual report how such considerations have been addressed. The Law on Public Pension Reserve Funds, also passed in 2001, requires pension funds' management board to regularly report to the supervisory board on how investment policy guidelines have addressed social, ethical, and environmental considerations.

In recent years, France carries a great importance to environmental concern; French government had passed many regulations and laws about the environment protection, we present, below, some laws:

- $\quad$ Law n²011-835 of 13 July 2011 prohibiting the exploration and mining of hydrocarbon liquids

\footnotetext{
${ }^{2}$ we refer to "societal" both "social" and "environmental" dimensions
}

and gases by hydraulic fracturing and to repeal the exclusive licenses awarded to projects using this technique - published in the OJ on July 14, 2011.

- Decree n²011-828 dated 11 July 2011 published in the Official Journal on 12 July 2011 defines the content of departmental and interdepartmental management plans concerning the prevention of waste from construction sites and public works as well as their preparation procedure.

- Decree n²011-829 dated 11 July 2011 published in the Official Journal on 12 July 2011 defines the content of a greenhouse gas emissions statement that must be issued by certain companies, local authorities and the State, as well as the arrangements for making this available to the public.

In the area of environmental and sustainability reporting, French companies have a good reputation in terms of social and environmental disclosure compared to many other European and American firms (Quairel-Lanoizelée 2011). All that is about to change with the newly amended "Nouvelles Régulations Economiques-NRE" (New Economic Regulations: NER), a French law that will oblige all French listed companies to communicate to shareholders and stakeholders on a range of sustainability issues, including many items (such as the environment, employees ...). The French Law on NER aims at adding an "ethical" feature to economic activities by French corporations and it was intended to update France's company law framework.

As the Law was implemented in January 2002, now it is possible to evaluate the degree of success of firms in terms of legitimacy vis-a-vis the environment and Community. In fact, some expectations have been formulated by The Social and Environmental Rating Agency (ARESE), which might give some ideas of the quality of implementation and the final effects of the law; as well, this agency confirms the progress of French companies' awareness about societal concern.

AFNOR lead actor of the French standardization system is the French member of ISO. By 2000, AFNOR and its partners have initiated discussions on the need to standardize social responsibility. These reflections helped publish the first document in French 2003: SD 21000: Guide for the consideration of sustainability issues in the strategy and management of the company.

Thus, France was already in "running order" to rule on whether or not to promote the launch of ISO 26000. She immediately opened a standardization committee "sustainable development, social responsibility".

Adding that, the translation working versions of the ISO 26000 standard was conducted by the AFNOR. This association has been chosen by ISO as the official responsible for the translation of the future standard in French.

In order to reinforce the transparency and responsibility of their companies, and in parallel to 
the initiatives explained above, France has produced a National Strategy for Sustainable Development which was presented at the World Summit on Sustainable Development in Johannesburg. The strategy was published by the ministry responsible for the environment, known now as the Ministry of Ecology and Sustainable Development. This strategy replaces the previous version, which was implemented in 1996 and had 35 proposals under 8 topic headings:

- Involving government authorities;

- $\quad$ Placing people at the heart of policy making;

- Transparency and evaluation;

- Citizenship and education;

- Mobilizing economic players;

- Strengthening the role of civil society;

- Spatial planning; and

- Promoting safe, clean, energy-efficient technology.

The French Sustainable Development Commission is an independent advisory body working under the direct authority of the Ministry of Ecology and Sustainable Development. The Commission (SD) was created in 1993 with a role of promoting debate on the subject of sustainable development amongst civil society in France. Whilst not an overall coordinating body, it does play an important role with the promotion of SD within French society. For a period after its creation, it focused on producing and disseminating numerous different analyses and documents attempting to help translate the abstract concept of SD into a concrete reality. Nowadays, however, it is a high-level multidisciplinary panel, consisting of different representatives from French society (encompassing scientists, economists, lawyers, teachers, the liberal professions, farmers and trade unionists etc.). It is meant to act as an interface between experts and civil society, and regularly produces reports for the Prime Minister on a range of different subjects, many of which are relevant to SD.

The French Institute for the Environment is a public establishment subordinated to the Ministry of Ecology and Sustainable Development. Since 1997 it has been working on the development of SD indicators at a national level and testing the current theoretical framework to make sure it is flexible enough to be applied to indicator development.

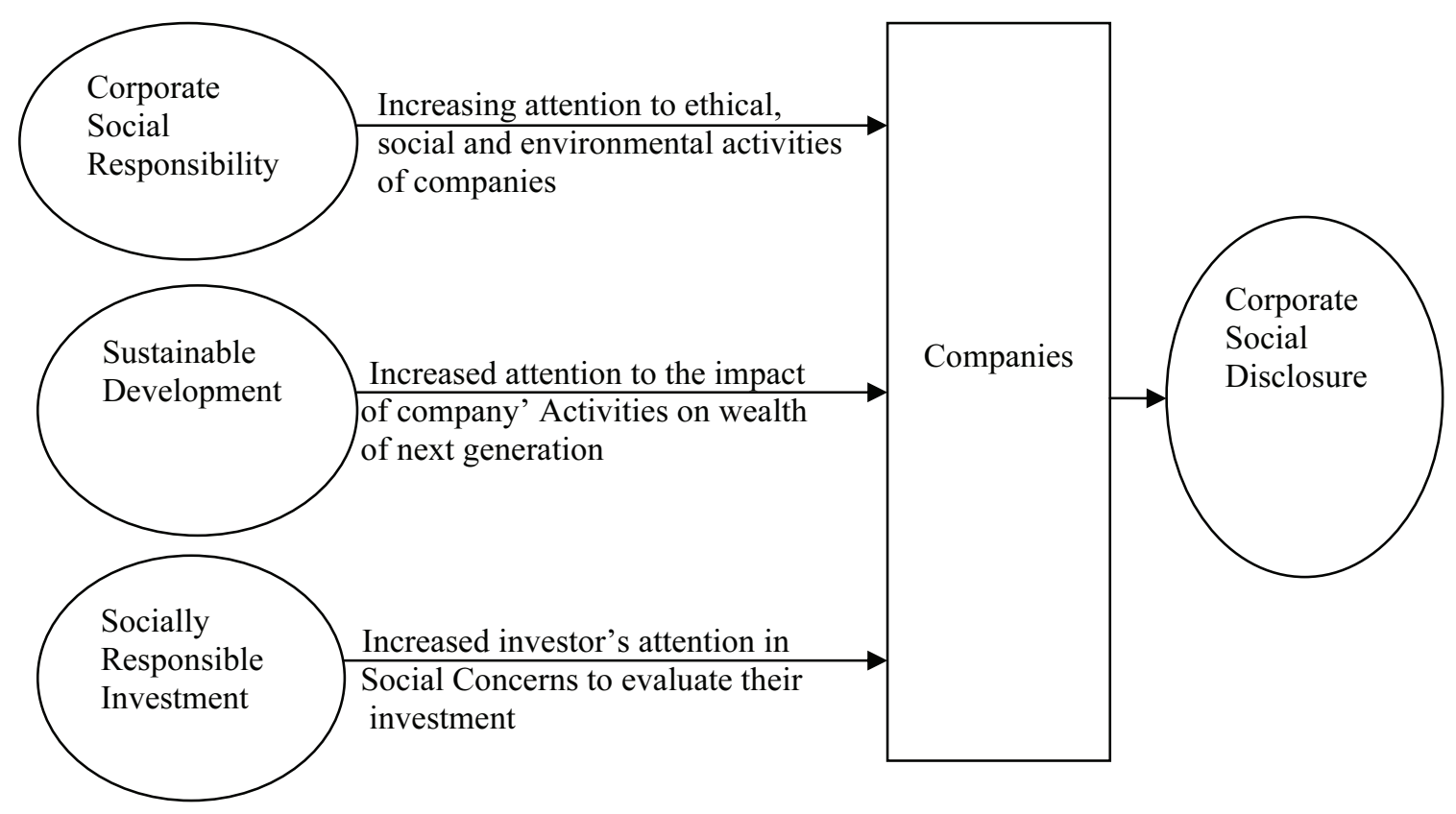

Fig. 1. $\quad$ Corporate social disclosure and its related concepts (Hassan 2010)

\section{Methods}

\subsection{Sample selection and data}

France is ranked $4^{\text {th }}$ with a publication rate of an environmental report (or sustainable development report) by its largest companies (Capron 2003, p. 4). Cormier and Magnan (2003, p. 1) talked about pressures exerted on French companies, by the market, in the purpose to disclose more and good information about the effects of their activities. Any time, the current economic crisis has strengthened even more discussion on this theme of communication on social responsibility. France's commitment to CSR is characterized by both its full participation in many international negotiations. This commitment is stated in terms of legislation including the Law on New Economic Regulations and the Law $N^{\circ} 2010-788$ of 12 July 2010 related to a national commitment to environment. Also, we note the promotion of responsible investment by various devices and improving transparency with a labels policy. Finally, initiatives by private actors demonstrate the collaboration of French society in corporate social responsibility. 
Our data (annual reports) are gathered from the Worldscope and Data Stream. Our study focuses on a final sample of 128 non-financial companies as part of SBF 250 index between 2005 and 2010. The number of population companies was 250, the elimination of some companies is for these reasons:

- the financial companies

- date of the financial year end is different from 31 December

- firms missing the data necessary to measure the variable

We are based on web sites of companies and some web sites such as: www.euronext.com, www.amf-france.com, to download all annual reports and special reports (sustainable development report, environmental report ...) of our companies' sample.

\subsection{Measure of social and environmental disclosure}

For measuring environmental and social disclosure, a review of past research shows several techniques. The majority of studies, in the field, have used content analysis method based on indexing and weighting scales (Wiseman 1982; Patten 1991, 1992; Patten and Nance 1998).

According to Wiseman (1982) the simplest structure of content analysis techniques makes out the presence or absence of bring up of a particular event in a document (annual report for example).

Previous studies assessed environmental disclosures mainly from annual reports and other regulatory filings such as $10 \mathrm{Ks}$ and many of those studies rely on a Wiseman (1982) based content analysis index to measure the extent of environmental disclosure. The Wiseman index focuses on the financial consequences of corporate environmental activities and puts more weight on quantitative disclosures. Using this measure, poor environmental performers may actually have higher disclosures cores than good performers because they have greater exposures and must discuss any material financial information in their regulatory filings such as annual reports and $10 \mathrm{Ks}$.

After the emergence of new normalizations attempts on international and French levels, such as the French law for New Economics Regulations (2002), the Global Reporting Initiative (Clarkson, Overell and Chapplle 2011), the Global Compact and the ISO 26000, we opt to a scale composed from 58 items (Tables 1 and 2). This scale encompasses both environmental and social aspects. Index items are empirically verified by Ben Rhouma (2008), Aerts, Cormier and Magnan (2008) and recently by Cormier et al. (2011).

The rating is based on a score from zero to three; three points are awarded for an item described in monetary or quantitative terms, two when an item is described specifically, one for an item discussed in general and zero for no information about the item.
Table 1. Items for Environmental Disclosure level measurement

\begin{tabular}{|c|c|}
\hline Dimensions & Terms \\
\hline $\begin{array}{l}\text { Expenditures and } \\
\text { risks }\end{array}$ & $\begin{array}{l}\text { - Investments } \\
\text { - Operation costs } \\
\text { - Future investments } \\
\text { - Future operating costs } \\
\text { - Financing for investments } \\
\text { - Environmental debts } \\
\text { - Risk provisions } \\
\text { - Risk litigation } \\
\text { - Provision for future } \\
\text { expenditures }\end{array}$ \\
\hline $\begin{array}{l}\text { Laws and } \\
\text { regulations } \\
\text { conformity }\end{array}$ & $\begin{array}{l}\text { - Litigation, actual and } \\
\text { potential } \\
\text { - Fines } \\
\text { - Orders to conform } \\
\text { - Corrective action } \\
\text { - Incidents } \\
\text { - Future legislation and } \\
\text { regulations }\end{array}$ \\
\hline $\begin{array}{l}\text { Pollution } \\
\text { abatement }\end{array}$ & $\begin{array}{l}\text { - Emission of pollutants } \\
\text { - Discharges } \\
\text { - Waste management } \\
\text { - Installation and process } \\
\text { controls } \\
\text { - Compliance status of } \\
\text { facilities } \\
\text { - Noise and odors }\end{array}$ \\
\hline $\begin{array}{l}\text { Sustainable } \\
\text { development }\end{array}$ & $\begin{array}{l}\text {-Natural resource } \\
\text { conservation } \\
\text {-Recycling } \\
\text {-Life cycle information }\end{array}$ \\
\hline $\begin{array}{l}\text { Land remediation } \\
\text { and contamination }\end{array}$ & $\begin{array}{l}\text {-Sites } \\
\text {-Efforts of remediation } \\
\text {-Potential liability- } \\
\text { remediation } \\
\text {-Implicit liability } \\
\text {-Spills (number, nature, } \\
\text { efforts of reduction) }\end{array}$ \\
\hline $\begin{array}{l}\text { Environmental } \\
\text { management }\end{array}$ & $\begin{array}{l}\text {-Environmental policies or } \\
\text { company concern for the } \\
\text { environment } \\
\text {-Environmental management } \\
\text { system } \\
\text {-Environmental auditing } \\
\text {-Goals and targets } \\
\text {-Awards } \\
\text {-Department, group, service } \\
\text { affected to the environment } \\
\text {-ISO 14000 } \\
\text {-Involvement of the firm in } \\
\text { the development of } \\
\text { environmental standards } \\
\text {-Involvement in } \\
\text { environmental organizations } \\
\text { (e.g. industry committees) } \\
\text {-Joint projects with other } \\
\text { firms providing } \\
\text { environmental management } \\
\text { services }\end{array}$ \\
\hline
\end{tabular}


Table2. Items for Social Disclosure level measurement

\begin{tabular}{|c|c|}
\hline Dimensions & Terms \\
\hline $\begin{array}{l}\text { Labor practices } \\
\text { and decent work }\end{array}$ & $\begin{array}{l}\text { Absenteeism and reasons } \\
\text {-Employment opportunities } \\
\text {-Labor rights / Job creation } \\
\text {-Rehiring, accompanying, } \\
\text { social communication } \\
\text {-Equity programs } \\
\text {-Human capital development / } \\
\text { training } \\
\text {-Accidents at work } \\
\text {-Health and safety programs } \\
\text {-Employee savings }\end{array}$ \\
\hline Society & $\begin{array}{l}\text { Regional development } \\
\text {-Gifts and sponsorships } \\
\text {-Business ethics / measures } \\
\text { anti-corruption } \\
\text {-Strategic alliances } \\
\text {-Community involvement } \\
\text {-Dispositions of the - } \\
\text { International Labor } \\
\text {-Organization groups, } \\
\text {-Relations with stakeholders } \\
\text { (environmental grations, ...) } \\
\text { consumer association }\end{array}$ \\
\hline $\begin{array}{l}\text { Consumer and } \\
\text { product } \\
\text { responsibility }\end{array}$ & $\begin{array}{l}\text { Purchases of goods and } \\
\text { services } \\
\text { Product-related incidents } \\
\text { Product development and } \\
\text { environment } \\
\text { Consumer health and safety } \\
\text { /Product safety }\end{array}$ \\
\hline
\end{tabular}

We consider that the use of a coding scale to qualify a firm's Social Environmental Disclosure (SED) is appropriate for two causes. First, it allows for some incorporation of different sorts of information into a single figure that is comparable across firms in terms of importance. Second, while other disclosure studies rely on word counts to measure environmental disclosure (e.g., Neu, Warsame and Pedwell 1998; Williams and Ho Wern Pei 1999), a qualitative scale allows for the researcher's judgment to be used in rating the value or quality of the disclosures made by a firm. While this process is more subjective, it guarantees that irrelevant or redundant generalities are not regarded as strategic social and environmental disclosure (Aerts et al. 2008).

\section{Results and Discussion}

Items of variable (SED) measurement are subdivided into two dimensions: social disclosure (SOCDISC) and environmental disclosure (ENVDISC).

The first dimension is composed by three categories, the second encompasses sixth categories.

We note that SED mean is 73.875 , compared to the maximum value possible which can be obtained (174) (calculated as: the maximum value accorded to an item multiplied by the total number of items, i.e., $3 * 58=174$.). Despite the mandatory requirement of the environmental and social disclosure of French listed companies, the disclosure level is very low. But, this average has increased compared to what was found in the studies before the advent of the French law about the new economic regulations of 2002; the thesis of Ben Rhouma (2008) shows three means of social and environmental disclosure of 2001, 2002 and 2003, she obtained 21.7, 44.98 and 58.95, respectively.

Table 3. Descriptive statistics of social and environmental disclosure, its two dimensions, and their categories

\begin{tabular}{|l|c|c|c|c|c||}
\hline Variables & Obs. & Mean & Std. Dev. & Min & Max \\
\hline Composite score: SED & 759 & 73.875 & 39.571 & 5 & 155 \\
\hline First dimension: SOCDISC & $\mathbf{7 6 1}$ & $\mathbf{3 6 . 3 4 7}$ & $\mathbf{1 4 . 4 9 8}$ & $\mathbf{2}$ & $\mathbf{5 1}$ \\
\hline First category: Labor practices and decent work & 761 & 12.754 & 6.312 & 0 & 21 \\
\hline Second category: Society & 761 & 12.727 & 5.389 & 1 & 17 \\
\hline Third category: Consumer and product responsibility & 761 & 9.342 & 3.076 & 1 & 13 \\
\hline Second dimension: ENV_DISC & $\mathbf{7 6 1}$ & $\mathbf{3 7 . 4 8 2}$ & $\mathbf{2 9 . 0 5 3}$ & $\mathbf{3}$ & $\mathbf{1 0 4}$ \\
\hline First category: Expenditures and risks & 761 & 9.301 & 3.015 & 1 & 27 \\
\hline Second category: Laws and regulations conformity & 761 & 5.456 & 1.498 & 0 & 17 \\
\hline Third category: Pollution abatement & 761 & 3.345 & 1.174 & 1 & 13 \\
\hline Forth category: Sustainable development & 761 & 2.989 & 1.086 & 0 & 6 \\
\hline Fifth category: Land remediation and contamination & 761 & 4.344 & 2.199 & 0 & 13 \\
\hline Sixth category: Environmental management & 761 & 12.047 & 5.034 & 1 & 28 \\
\hline
\end{tabular}

Our first conclusion, the two means of disclosure for both dimensions are close. We conclude that French firms are interested by the two aspects of environment and community, the two dimensions occupy a great place in the strategy of companies, and many authors talk about "greenwashing strategy" (Clarkson et al. 2006).
On the other hand, we note that French companies look seriously to environmental matters and they are keenly interested by laws and regulations about pollution and environmental management.

In an environment of increased ethical scrutiny and competition, French companies must develop strategies to meet seemingly contrary business goals, 
namely, commitment to ethical standards and commitment to making a profit, and to identify and respond to specific stakeholder needs. Many advantages could be obtained from these social and environmental strategies; CSR practices provide opportunities for organizations to differentiate themselves in the marketplace by adding social activity as a value-added factor to products and services.

\section{Conclusion}

In this paper by evaluating the scope of social and environmental disclosure in France, we have obtained an acceptable level compared to that found by Ben Rhouma (2008); from this finding, we think that French companies are in evolution in social and environmental responsibility and they are more ethical. But compared to Anglo-Saxon companies, the French companies are far from the rank of corporate citizens. Disclosure of information on more responsible activities can be considered to be an influencing factor in the attainment of social and environmental awards (Hassan and Ibrahim 2012). The identification of a high level of disclosure on these specific activities indicates that firms in our sample perceive disclosure on them to be extremely important. The level of disclosure on these activities, and the consequent possibility of attaining an award, is influenced by many factors.

Our study may suffer from some limitations, there is an imbalance in the number of items that make up the two dimensions of disclosure, we have a number higher for the environmental disclosure than for social disclosure, and consequently our results were partially biased. For this, current items could be updated or revised by referencing to new French acts or regulations in the social and environmental field; the new items may be confirmed by qualitative research.

Finally, for more generalized findings, we attempt to conduct empirical research on large sample which covers all French Stock Exchange companies or to make a comparative survey in the Union European firms.

Also, we will be able to search the determinants or factors explaining the level of social and environmental disclosure.

\section{References}

AERTS, W., CORMIER, D. and MAGNAN, M. Corporate environmental disclosure, financial markets and the media: An international perspective. Ecological Economics, 2008, 64, 6 p. http://dx.doi.org/10.1016/j.ecolecon.2007.04.012

CAPRON, M. L'Economie Ethique Privée : La responsabilité des entreprises à l'épreuve de l'humanisation de la mondialisation. Economie Ethique $\mathrm{N}^{\circ} 7$, United Nations Educational, Scientific and Cultural Organization, Paris, 2003.

CAPRON, M. and GRAY, R. Experimenting with Assessing Corporate Social Responsibility in France: An
Exploratory Note on an Initiative by Social Economy Firms. The European Accounting Review, 2000, 9(1), p. 99-109. http://dx.doi.org/10.1080/096381800407969

CLARKSON, M.P., OVERELL, B.M. and CHAPPLE, L. Environmental Reporting and its Relation to Corporate Environmental Performance. ABACUS, 2011, 47(1), p. 27-60. http://dx.doi.org/10.1111/j.1467-6281.2011.00330.x

CLARKSON, P.M., LI, L., RICHARDSON, G.D. and VASVARI, F.P. 2006. Revisiting the relation between environmental performance and environmental disclosure: An empirical analysis: The University of Queensland and University of Toronto.

CORMIER, D. and MAGNAN, M. Environmental reporting management: a continental European perspective. Journal of Accounting and Public Policy, 2003, 22 (1), p. 4362. http://dx.doi.org/10.1016/S0278-4254(02)00085-6

CORMIER, D., LEDOUX, M.J. and MAGNAN, M. The Informational Contribution of Social and Environmental Disclosures for Investors. Management Decision, 2011, 49(8), p. 1276-1304. http://dx.doi.org/10.1108/00251741111163124

Dam, L. and Scholtens, B. Does Ownership Type Matter for Corporate Social Responsibility? Corporate Governance: An International Review, 2012, 20(3), p. 233-252 http://dx.doi.org/10.1111/j.1467-8683.2011.00907.x

FRIEDMAN, A.L. and MILES, S. Socially Responsible Investment and Corporate Social and Environmental Reporting in the UK: An Exploratory Study. British Accounting Review, 2001, 33, p. 523-548. http://dx.doi.org/10.1006/bare.2001.0172

GOND, J.P. 2006. Constructing the positive relationship between corporate social and financial performance on financial markets. Conférence Internationale De Management Stratégique, Annecy/Genève, 13-16 June.

HASSAN, A. and IBRAHIM, E. Corporate Environmental Information Disclosure: Factors Influencing Companies' Success in Attaining Environmental Awards. Corporate Social Responsibility and Environmental Management, 2012, 19, p. 32-46. http://dx.doi.org/10.1002/csr.278

HASSAN, N.T. 2010. Corporate social responsibility disclosure: an examination of framework of determinants and consequences. Doctoral thesis, Durham University.

NEU, D., WARSAME, H. and PEDWELL, K. Managing public impressions: environmental disclosures in annual reports. Accounting, Organizations and Society, 1998, 23, p. 265-282. http://dx.doi.org/10.1016/S0361-3682(97)00008-1

PATTEN, D. Intra-industry Environmental Disclosure in Response to the Alaska oil spill: A Note on Legitimacy Theory. Accounting, Organizations and Society, 1992, 1, p. 471-75. http://dx.doi.org/10.1016/0361-3682(92)90042-Q

PATTEN, D.M. and NANCE, J.R. Regulatory cost effects in a good news environment: The intra-industry reaction to the Alaskan oil spill. Journal of Accounting and Public Policy, 1998, 17, p. 409-429. http://dx.doi.org/10.1016/S02784254(98)10007-8

PATTEN, D.M. Exposure, Legitimacy, and Social Disclosure. Journal of Accounting and Public Policy, 1991, 10, p. 297-308. http://dx.doi.org/10.1016/0278-4254(91)90003-3

QUAIREL-LANOIZELÉE, F. Are competition and corporate social responsibility compatible? The myth of sustainable competitive advantage. Society and Business

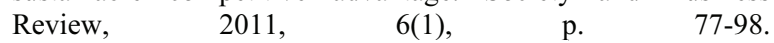
http://dx.doi.org/10.1108/17465681111105850

WILLIAMS, S.M. and HO WERN PEI, C.A. Corporate social disclosures by listed companies on their web sites: an international comparison. The International Journal of Accounting, $2009, \quad 34, \quad$ p. $389-419$. http://dx.doi.org/10.1016/S0020-7063(99)00016-3

WISEMAN, J. An evaluation of environmental disclosures made in corporate annual reports. Accounting, Organizations and Society, 1982, 4(1/2), p 123-133. 
Ben Mahjoub Lassaad, $\mathrm{PhD}$ Student, Unit of Research: Corporate Finance and Financial Theory, Faculty of Economic Sciences and Management, Sfax, Tunisia

Main research area: communication about social and environmental information, CSR, earnings quality

Address: $\quad$ Route Sidi Mansour

Tel.:

Km 10 B.P 43 - 3061, Sfax, Tunisia

E-mail:
Halioui Khamoussi, Professor of Accounting, College of Economics, Management and Information Systems, University of Nizwa, Oman

Main research area: management accounting, management control, financial accounting, corporate governance

Tel.:

$00216 / 98641583$

E-mail:

\title{
İmonių bendravimas siekiant socialinès atsakomybès ir darnios plètros Prancūzijoje
}

\author{
Ben Mahjoub Lassaad ${ }^{1}$, Halioui Khamoussi ${ }^{2}$ \\ ${ }^{1}$ Apskaitos ir finansu katedra, Ekonomikos mokslu fakultetas, Sfaksas, Tunisas \\ ${ }^{2}$ Ekonomikos kolegija, OmaNAS
}

(gauta 2012 m. vasario mèn., priimta spaudai 2012m. rugsèjo mèn.)

Prancūzija yra pagrindinių Europos kultūrinių srovių kryžkelèje, nusidriekusi tarp Šiaurès Europos ir Viduržemio jūros regiono, todèl joje skiriamas didelis dėmesys socialinei atsakomybei ir darniai plètrai. Šiems klausimams spręsti buvo atlikta daug socialinių ir aplinkos tyrimų, tačiau tai nevisiškai atspindi gamtosauginių ir socialinių dalykų aktualumo.

Atliekant naujus matavimus, buvo stengiamasi nustatyti įmonių socialinès atsakomybès lygi Prancūzijoje. Atitinkamai analizei parinkti indeksai, kuriuos naudojant atlikta analizè, ịvertinta ir apibrèžta įtaka aplinkai bei bendruomenèms.

Palyginus su kitais tyrimais, šis tyrimas parodè, kad socialinè ir aplinkosauginè informacija priimtina Prancūzijos įmonėms. 